Silences, categories and black-boxes: towards an analytics of the relations of power in planning regulation

Yvonne Rydin

Bartlett School of Planning

University College London

14 Upper Woburn Place

London

WC1H ONN

Y.Rydin@ucl.ac.uk

02031089562 


\section{Silences, categories and black-boxes: towards an analytics of the relations of power in planning regulation}

\section{Introduction}

Regulation seems to be a classic tool of government. It involves the exercise of the state's sovereign authority to force someone to do or not to do something. In the realm of planning, regulatory processes decide where development can and cannot occur and also many of the details of development: height, building materials, aspects of design, environmental features and so on. And, because of this control, it offers a space for negotiation; developers faced with the need to acquire consent to develop may be willing to bargain with planners, local communities, environmental agencies or other actors, making changes to their proposals or offering additional social and environmental benefits. The nature of the control and bargaining will vary with the specific planning regime and how it authorises development but planning cannot proceed, in a market-based economy where private development is the norm, without some form of regulation of the private sector by the public sector.

This is the conventional framing of regulation and it readily leads to a debate about the nature of this control. On one side of this debate is the negative characterisation of those opposing development as NIMBY, pursuing their own interests and preventing sociallyneedful and wealth-creating development. This can be supplemented with an emphasis on the planner as a bureaucrat holding excessive discretionary power over the regulatory decision. On the other, there is the view that planning regulation is constrained and that 
power rests with the developer so that it is relatively easy to get planning permission or 'game' the planning regime to the developer's advantage.

While not denying that this expresses many actors' experience of the regulatory process, the argument here is that power is at work within regulation in a different way. The paper, in the Foucauldian vein, seeks to unsettle the 'taken-for-granted', the 'given' (Lennon and Fox-Rogers, 2017: 366). Rather than seeing power as a resource that is controlled by actors (the first dimension of power in Lukes, 2005), power is seen as emergent, in line with the relational thinking of the Foucauldian tradition and the ontologically-aligned Actor-Network Theory (ANT). It is evident in the performative dimension of regulatory processes, whereby elements that might seem to be 'external' to the regulatory regime are constructed within it, and activated in the way that knowledge is implicated in regulatory processes and knowledge claims are used as the basis for regulatory decision-making.

Using this understanding of power, a specific case of regulation is analysed, highlighting the importance of silences, categorisation and black-boxing. This builds on research into the post-2008 regulatory regime in England and Wales concerning major renewable energy projects. After setting out the distinctive features of planning regulation, the conceptual framing is developed more fully, and then the paper sets out the regime established by the Planning Act 2008 and outlines the research that it draws upon. The analytic part of the paper is structured in three sections and the conclusion draws out the implications for regulatory reform and planning theory.

\section{The distinctive nature of planning regulation}


Black (2001) provides a definition of regulation, starting from a legal perspective: the intentional use of authority to affect behaviour of a different party according to set standards, involving instruments of information-gathering and behaviour modification. This sees regulation as a process or set of practices rather than the regulatory artefact alone. Thus the form of planning regulation discussed here concerns less the zoning ordinance or formally binding land use plans (Davy, 2012) but rather case-by-case consideration of and decision-making on development proposals. It is tempting to see such regulation purely as involving "coercive means" (Davy, 1997: 4) or the sovereign power of the state (Kamete, 2001) through which the state implements plans. However, this is to underestimate both the agency of regulation as a specific set of relations and the way that power is thereby produced. The conceptual framing will elaborate this and the case study will illustrate it but, first, it is important to clarify the distinctive nature of planning regulation and, therefore, how its theorisation will differ from that of the drawing up of plans or the management of urban regeneration projects, say.

Regulation within a planning context acts as an obligatory passage point (to borrow an ANT term; Callon, 1986) through which development projects must pass to receive permission or consent. At this point the relations of the proposed project and the regulatory regime come together in new sets of associations to produce new forms of agency. This is a pausing point in the urban development process at which the project comes under scrutiny. There is a decision-maker (which may be local or central government or even an independent body) and the implications of the decision carry weight, not only in that they allow the development to go forward but also that economic value is thereby created (Davy, 1997). The decision also has weight in that regulatory decisions do not occur in isolation but tend 
to look back at past decisions and forward to future development applications. The institutional norms of regulatory institutions are usually that there should be a degree of consistency in such decisions over time (Lennon and Fox-Rogers, 2017: 375).

Time also features within regulatory processes because the decision-making on individual cases has to be time-limited to some extent. In the case that is discussed below, there are fixed time limits for the different stages in the regulatory process. The existence of such time constraints impacts on the way that knowledge about the project, its environment and its likely impacts emerges and is handled. Time constraints here can compound cognitive limits in handling multiple sets of knowledge claims. It also needs to be recognised that such knowledge often involves uncertainties, not least because it is concerning the future: how a project that is not yet built will turn out, be managed and impact on a locality, which may itself be changing. One key aspect of regulation is how uncertainty over time is managed in a situation where a decision has to be made in the present.

These dynamics exert influence on how attention within regulation is directed. Attention is a limited resource: staff time and budgets to investigate aspects of a proposal are limited; time is often pressing; and the desire to be comprehensive in considering a development proposal will be impacted by the cognitive limits on understanding and considering all aspects in relation to each other. In such a context, it matters where attention is directed; where the focus lies, what it ignored and what counts as relevant knowledge. Attention approaches a zero-sum game. Attention to overt conflicts within regulation can contribute to a lack of appreciation of issues that are not being fully considered. Thus, a focus on NIMBY conflicts and what different interests want from planning regulation, for example, 
draws attention away from the extent to which certain aspects of concern have been deregulated and not able to be considered within regulatory decision-making at all. Furthermore, warranted knowledge draws regulatory attention in specific directions so that certain accounts about the world and how it might be changed dominate. The paper now makes explicit the conceptualisation of power involved in analysing such regulation.

\section{Towards an analytics of the relations of power}

Regulation is a power-infused process. In itself this is not a surprising statement. The question is how to understand and theorise power. Rather than seeing power as "a commodity, a position, a prize, or a plot" (Dreyfus and Rabinow, 2006: 185), the approach adopted here follows the Foucauldian view: "If power is not a thing, or the control of a set of institutions, or the hidden rationality to history, then the task for the analyst is to identify how it operates" (ibid), that is it seeks an analytics of the relations of power. Power is immanent to institutions but institutions and power are not identical; the question is how power operates within an institution, such as the regulatory regime of a planning system. In a Foucauldian approach, power is understood as "an open, more-or-less coordinated (in the event, no doubt, ill-coordinated) cluster of relations" (Foucault, 1982: 184). Power here is an emergent property of relationships between actors, between entities and, as Metzger et al. emphasise (2017:207) has itself to be explained.

Foucault's view of power as emergent has not been without its controversies. Some of this relates to the way that Foucauldian ideas entered into planning studies, initially through Flyvbjerg's book on Rationality and Power (1998), which has been criticised for assuming the reproduction or reinforcement of existing asymmetries of power relations (Metzger et al., 
2017: 206; see also Yiftachel, 2001). This criticism seems well-founded and speaks to the need to examine each case afresh: as Foucault himself said, "I think the word rationalization is dangerous. What we have to do is analyse specific rationalities rather than always invoking the progress of rationalization in general" (1982: 210). There are three dimensions that are emphasised here in undertaking such an examination: the nature of power as securing consent; the performativity of practices and processes; and the centrality of knowledge claims.

\section{Power as securing consent}

In the reworking of his classic book on power, Lukes explores the Foucauldian character of his 'third dimension of power'. Power, here, acts in a 'capillary' way dispersed across society. It is about "averting both conflict and grievance through the securing of consent" (Lukes, 2005: 111). While earlier formulations linked this third dimension to control over the policy agenda and the exercise of ideology within society, in his later work, Lukes engages fully with Foucault's ideas; this looks to the role of discourses and practices in shaping communication, behaviour, action and even identities (2005: 121). The role of governing including regulation - can be understood through "discursively produced and circulated rationalities connected to, and inflected by, material practices and actions" (Huxley, 2006: 773).

Rather than emphasising force, social control is more likely to arise from "the construction of a common mind and language" (Melossi, 2006: 6). Power is here seen as "willing compliance" (Lukes, 2005: 106), in which people often act as their own "overseers"; people may see themselves as free, operating under their volition and coming to conclusions 
through rational of decision-making, but this face of power sees control and domination still at work. This idea of individuals acting as 'overseers' of the self is extended in the idea of governmentality (Miller and Rose, 1990), where Foucault's view of governing as the 'conduct of conduct' is complimented by the concept of self-responsibilisation, a mode in which the state is able to govern 'at a distance' because the work of governing is internalised by actors (Raco and Imrie, 2000). Regulation is, thus, less about the state directing the location and details of development and more about actors internalising regulatory norms. For example, Harris (2011) uses Foucault's work to look at the role of surveillance by the self and by neighbours in the enforcement of planning regulation. The questions are: which aspects of regulation become internalised so that actors align themselves with the project of governing? How does this work and who benefits? Ultimately whose project of governing is being prioritised?

Such power - capillary in nature and anchored in micro-practices - impinges on all but never equally. While Fraser (1992) argues that Foucault variously describes power as positive, negative and even neutral, many have found the approach particularly useful for studying inequalities. This involves drawing a link between the way that conduct is governed through relations of power and forms of rationality, on the one hand, and the privileging and/or marginalising of various actors and their ideas (Lennon and Fox-Rogers, 2017: 367). This remains essentially an empirical question. For example, in his study of planning in African cities, Kamete (2011) uses the Foucauldian categories of sovereign, disciplinary and pastoral power and finds that while pastoral power (changing hearts and minds) tends to be used in relation to more affluent groups who breach planning regulations, the poor are entangled in the exercise of sovereign power involving force. 


\section{Performativity of processes and practices}

The second thread in the conceptual framing is that of performativity. This concept is often cited as having its roots in the work of Austin (1963) looking at speech acts and how these not only describe reality but "bring reality into being" (Merkus and Weenswijk, 2017: 1265). A classic example is the speech of the marriage celebrant: "I pronounce you husband/wife and husband/wife". However, the concept has been taken up to discuss the power of narratives to generate change beyond the discursive realm, so that repeated utterances create and constrain the phenomena they appear simply to be expressing (Gregson and Rose, 2000). In the study of regulation, with its numerous utterances and texts, this is particularly helpful. Discursive repetition within regulation contributes to the creation of categories that otherwise seem to be pre-existing entities that regulators are merely engaging with. This concerns categories of actors, impacts and evidence. These cannot be seen as pre-existing, inevitable 'chunks' of reality; rather they are enacted through the regulatory process. However, it is not suggested that the regulatory process alone creates; rather, in line with ANT, they are co-created alongside the socio-materiality of actors, the project, the site and the environment (Latour, 2005). One area that is of particular interest is the way that performativity is involved in the constitution of the subject. For example, in her study of climate change planning, Webber (2013) emphasises performativity as a dynamic process whereby identities are made and remade; the appearance is created of natural conditions underlying those identities so that the identities themselves are not questioned; the result is encounters between social actors that are uneven and powerladen. Power is at work in the creation of those identities. 
The planning system is an important space within which representations of actors and evidence about project impacts are given expression, re-presented and framed (Wagenaar and Wilkinson, 2015). The significance is that the resulting constructions then become the official account, set down in formal documents, of what identified actors are concerned about or aspire to and what the significant impacts of a development proposal are. As Michael states: "social practices constitute givens which have consequences"; 'givens' here refers to "categories which would otherwise remain routinely unproblematized" (1995: 5). Pieraccini looks at this in the context of regulation to highlight how the interests that are taken for granted are actually framed and thereby produced through regulation (2015: 21) and Callon also has shown how, in a contentious road project, the groups of actors - and their identities - were constituted by the action of protesting in a public space (2010: 124). These are part of the 'dividing practices' that Foucault considered were particularly important to study (1982: 208) and, by studying these, it is possible to avoid the more structuralist tendencies of Foucault's thought, including the assumption of objective interests as a baseline for studying the effects of power (Metzger et al., 2017).

\section{Knowledge and power}

Huxley (1991: 79) begins her argument for a Foucauldian perspective on planning by quoting Foucault (2006: 771): the "problem is to see how men (sic) govern (themselves and others) by the production of truth". Foucault has further argued that "there is no power relation without the correlative constitution of a field of knowledge, nor any knowledge that does not presuppose and constitute at the same time power relations" (Foucault, 1977:27; see also Rouse, 2005). Foucault sees the 'will to truth' produced within a 'regime of truth' comprising objects, criteria, practices, procedures, institutions, apparatuses and operations 
(Fraser, 1992: 220). These create the separation of "those concepts deemed false from those that are considered true" (Lennon and Fox-Rogers, 2017: 367).

The planning system acts an important arena where knowledge is presented, discussed, examined and constructed as 'evidence'. Planning regulation is rooted in the avowed desire to know about and consider all the relevant dimensions of a development proposal. Knowledge of the project and the environment is central to the legitimacy of planning regulation, as is an understanding of future impacts extrapolated from an understanding of the current situation. Therefore, how knowledge claims are handled is a central aspect of regulatory practice. Knowledge is constructed within planning as an evidence-base for decision-making so that regulation is seen as rational and legitimate. However this is a contested process in which claims are made, contested and selectively warranted and where the material resistance of the world affects the process of warranting. Furthermore, knowledge claims give voice to certain issues (and by association, certain groups) and silence others. This may reinforce the overt exercise of power or it may subvert it, offering alternative avenues of power to those apparent in the visible clash of actors.

However, as outlined above, regulation is also a goal-oriented activity and always has the final decision in view. There is a certain pressure of time; the decision cannot be endlessly deferred. Generating knowledge claims accepted as robust can be time-consuming involving collecting data, building models, making assessments and debating these. There is not usually scope within regulatory processes to generate new knowledge that is widely accepted as reducing uncertainty about projects' impacts. Thus, various commentators have suggested that the knowledge required within regulation is rather specific. Jasanoff (2015) 
has termed such knowledge as 'serviceable truths'; it needs to be sufficiently fit for purpose to enable decision-making to proceed. Van Oorschott and Schinkel (2015) point out that the knowledge needed to enable judicial decision-making (which is close in character to regulatory decision-making) is that which renders the world judgement-compatible; that is, it needs to reduce complexity so that a judgement can be made. The sufficiency of the knowledge and its ability to simplify are the key characteristics that render it appropriate in a regulatory context.

In focussing on how knowledge is generated it is important also to be aware that knowledge claims necessarily involve uncertainty. Very few, if any, claims are accepted as fully and uncontestably true; rather there is a need to live with the uncertainties inherent in such claims. Similar, there will be gaps in knowledge on any particular issue or surrounding any particular project. Absences of knowledge and uncertainties in warranted knowledge are also important in understanding how power and knowledge are intertwined.

\section{Analysing planning regulation of major renewable energy infrastructure in England and Wales}

Planning regulation in the UK generally occurs through case-by-case assessment of development proposals, considering both alignment with policy documentation and the specific characteristics of the proposal and location. With a few exceptions, it is a plan or policy-led system, not a form of zoning. Most new development is regulated although some is exempted by General Development Orders and similar measures. Planning regulation is generally undertaken by local authorities but the regime for regulating major infrastructure examined here takes decision-making up to the central government level and involves the 
Planning Inspectorate (a central government agency). The nature of this regulatory regime and the research drawn upon will be briefly introduced.

Nationally Significant Infrastructure projects (NSIPs) are larger infrastructure projects, defined through central government-set thresholds and regulated by a regime established under the Planning Act 2008. A key feature of this regime is that it is time-limited once the application has been submitted. After submission, the Planning Inspectorate has three months to decide whether the application is fit to consider. After acceptance, there is a sixmonth examination. This is primarily a process of exchanging paper documents (evidence, reports, series of written questions and answers) but there are also hearings (open floor, issue-specific, concerning compulsory purchase, on the development consent order) and site visits. The conduct of the examination is broadly in the control of the Examining Authority (ExA) who can be an individual or a panel and is appointed by the Planning Inspectorate. Those concerned with and about the proposal can register as Interested Parties and they will be kept informed about progress. They are also able to present evidence, comment on submissions, answer questions, attend hearings and enter into statements of agreement with other Interested Parties.

The focus of the examination is avowedly on evidence-based decision-making with an inquisitorial approach taken to the evidence presented. In addition, policy documentation in the form of central government National Policy Statements (NPSs) plays an important role. After the examination concludes, the ExA writes a substantial report, including recommendations and a draft Development Consent Order (DCO), which then goes to the relevant Secretary of State within central government for the final decision. The DCO will 
have conditions attached and Section 106 agreements securing community benefits may be incorporated. Three months are allowed for the decision and then there is a final period for any legal challenge.

How is this set of regulatory arrangements operationalised and how is power exercised through them? The paper now turns to these questions building on the theoretical discussion above. This account draws on published research from a project undertaken during 2015-17 into the handling of major renewable energy (RE) projects (principally offshore and - in Wales - onshore wind farms but also biomass, energy-from-waste and tidal lagoon projects) within the NSIPs regime. The project studied 12 of the 16 cases that had passed through the regime at the start of the project (see Table 1) and analysed data collected from: close-reading and coding of ExAs' reports (supported by reading of supplementary material); a series of nine focus groups with local actors based in the vicinity of the proposed infrastructure projects; an online survey of all identifiable local participants in these cases; observation of other 'live' cases (at hearings, a site visit and a public exhibition); workshops with ExAs and developers; and interviews with community participation facilitators and national NGOs. The reports and focus group transcripts were coded for analysis using NVivo; survey results were analysed using descriptive statistics.

\section{[INSERT TABLE 1]}

Analysis proceeded by developing lines of argumentation inductively and deductively, supported by repeated and refined interrogation of the diverse research materials using NVivo and close reading. Triangulation of research findings and conclusions was enabled by 
using the different datasets developed from the documentation, focus group transcripts, survey results, interview transcripts and workshop/observation notes. This paper uses the results of this research to develop a theorised account of power and planning regulation. There is not space here to cite much of the empirical material and, thus, the reader is referred to published papers for more in-depth reporting and analysis of the findings. Three themes of analysis are developed: silences, categorisation and black-boxing.

\section{Theme 1 - Silences}

It is a frequent finding of planning research in many sites and domains that certain voices are silenced. This is often linked to differentials in actors' resources and procedural inadequacies affecting actors' access to the planning arena. Major RE infrastructure projects epitomise a clear imbalance between the different actors involved: the developer is investing in a multi-million-pound project and will allocate substantial sums to obtain the development consent; the expert agencies (Natural England or the Environment Agency) and local authorities will have statutory duties within regulation but, in times of public sector austerity, be constrained by their budgets; and NGOs (such as the Royal Society for the Protection of Birds) have to consider involvement in any specific examination against other priorities, campaigning, lobbying and involvement with other projects. Local communities - both residential and business - are likely to be less well-resourced, although there will be differences between local communities in this regard. This was apparent in the Navitus Bay offshore windfarm case where the local umbrella community group, Challenge Navitus, was able to pool sufficient local resources, expertise and energy to challenge comprehensively the case put forward by the developer and propose their own assessments of project impacts (Rydin et al., 2017). They had the benefit of a middle-class community 
based in one of the wealthiest property markets in southern England including professional expertise relevant to a planning dispute. This contrasted with the residential communities found in the other cases (Rydin et al., 2018a).

Certainly, looking across the case studies, the local actors who had been involved in regulatory decision-making experienced considerable frustration (Natarajan et al., 2018). While their perspective was not universally negative, there was widespread concern about the extent to which they were able to express their views, to be heard and to be taken into account over issues that mattered to them; processes of engagement and information provision were often criticised. The focus groups revealed how difficult local people found it to speak at public events and engage fully with regulatory processes. Some noted the limited opportunity to ask questions they felt were important, including on measures for monitoring the implementation of the DCO and its conditions. The research found particular issues with local business involvement (Rydin et al., 2018a). Consultation with local businesses was uneven with fishing interests faring better than other sectors such as leisure/tourism due to the existence of a national-level protocol for engagement. Nevertheless, local businesses repeatedly reported concerns. There was an over-reliance on email, online documentation (and too much of it) and formal meetings, none of which meshed well with local businesses' everyday lives. Employing a local fisherman to support consultation (found in one case) was welcomed by other fishermen.

Yet much of the concern from local people came not from such procedural arrangements. Interviews with Examining Authorities (ExAs) stressed how many of those in charge of NSIPs proceedings make considerable efforts to engage with local communities and given them a 
voice; the research also revealed that some community participation facilitators do a lot to empower local residents and businesses, although this was variable across projects and local authorities. But, regardless, local people felt that they were facing a 'done deal' and that such involvement was often token in nature rather than a real opportunity to engage. There are two aspects that shape this silencing of local concerns.

The first relates to the framing of project impacts in relation to the need for RE infrastructure. The National Policy Statements (NPSs) begin from an assertion that it is in the national interest for infrastructure to be built and it was clear from the outset that the NSIPS regime was established to facilitate the consenting and hence the construction of such infrastructure (Lee et al., 2013; Cowell and Devine-Wright, 2018). The policy framework stresses the national need for the grant of development consent. This raises the question of how the presumption in favour of such projects can sit alongside commitments to public engagement (Lee et al., 2015). The presumption means that public participation is ultimately about 'how' not 'whether' with regard to these infrastructure projects, contributing to local communities' feeling that the decision is a foregone conclusion and that they are powerless in the face of such framing. They are left with negotiation over amendments to the projects and DCO, amendments which the ExAs spend considerable time discussing but which local people are unsure whether they will be fully implemented.

The second concerns the consideration of project impacts. Research pointed to the relative silence on the local socio-economic impacts of NSIPs (Rydin 2018a). These are often presented as uncertain with developers making vague commitments concerning local employment and supply chains. The fact that the Operations \& Maintenance ports for 
offshore facilities are not routinely specified further adds to this uncertainty. Uncertain impacts are given little weight within the discussions. This is exacerbated by analysis of socio-economic impacts at sub-regional, regional or even national scale, lacking the granularity required for understanding local impacts. Local businesses also expressed concern that the cumulative effects of multiple infrastructure projects on local businesses and the restructuring of the local economy more generally, which are of considerable importance to them, are not fully considered. Thus, the evidence presented on local socioeconomic impacts is often absent, of minimal quality and quantity and consequently judged by ExAs not to be robust enough to feed into decision-making.

By contrast, it is immediately apparent from the ExA reports that there is a mass of material on ecological impacts (Lee et al., 2019). There is considerable concern represented in these documents over the fate of species populations in the vicinity of an NSIP, including birds, fish, marine mammals such as porpoises and terrestrial species such as reptiles. The emphasis on this conservation of species within planning regulation provides a necessary check to over-emphasising deregulation; however, it also points to the way that regulatory law is involved in structuring the discussion about such ecological impacts. The mobilisation of bias towards ecological matters and, by implication, away from others arises from EU policy and legislation that requires the regulatory process to make a substantive judgement as to the likely ecological impacts, as opposed to just weighing it against other impacts, as with socio-economic concerns. Thus there is more consideration of 'fish stocks' - an ecological category - than 'fishermen's catches' - a socio-economic category.

\section{Theme 2 - Categorisation}


There is considerable efforts undertaken within the NSIPs regulatory processes to categorise and this concerns both actors and impacts.

Actors and their voices are performatively constructed within the operation of the regulatory process and this has implications as categories of actors are created and assumed identities associated with these categories. The research on the NSIPs regime suggested that local actors are constructed as quite distinctive categories of local voices (Rydin et al., 2018b). The voice of local residents is framed as highly individualised and based on proximity to the project. The emotional affect of place attachment (Devine-Wright, 2009) is acknowledged but there is more emphasis on what might be termed 'reasonable enjoyment' to judge the concerns of residents. This puts the stress on the sensory experience of anyone in the locality rather than the pre-existing emotional attachment of local residents. Local residential voices are rarely directly linked to mitigation measures during regulation. By contrast, local businesses voices are strongly framed in terms of economic impact and seen as a (limited) source of evidence of such impact; this leads directly to mitigation measures to offset such impacts, including the offer of financial compensation. Agreement on such mitigation measures typically render local business concerns silent.

The nature of local lives is thus simplified by the distinct framing of voices within regulation into different categories, which denies the way those lives result from inter-connected relationships within civil society and the local economy. The complexity of how a new major infrastructure project impacts on local communities is simplified and atomised into a set of distinct questions. Will reasonable enjoyment be impacted? Can the economic effects on 
businesses be compensated? Reconsidering the case of fishermen from the classic research by Callon (1986), Michael emphasises the "actions by which an entity attempts to impose and stabilize the identity of other actors" (ibid: 53) and stresses the way that creating such a stable identity involves delinking one actor from certain of their associations and imposing a role on that actor. This can be seen at work also in the case of NSIPs. Creating categories such as 'local resident' or 'local business' involves separating out overlapping associations by which one individual may be multiply connected through residence, employment and civil society activities or have connections beyond the locality. This reduces the potential of the complex interconnected stories of local lives being present within regulation.

But categorisation is also apparent with regard to project impacts, particularly concerning landscape evaluation (Lee, 2017; Rydin et al., 2018c). The key regulatory criteria applied to evidence is whether the level of impact is sufficient to require a response by the regulator, either by denying development consent or demanding mitigation measures. Categorisation is essentially as a means of communication across organisational and sectoral boundaries, a form of short-hand for regulatory discussions so that the scale rather than the detail of the impact becomes the focus. For NSIPs there is a specified rationale for categorising impacts their significance has to be rated and judged against the need for the infrastructure set out in the NPSs. Only very significant impacts can sway the decision against consent, and mitigation is focused on reducing the more significant adverse impacts to make the proposal acceptable. What counts as significant is key here.

Categorisation of impacts runs repeatedly throughout ExAs' reports as a means of justifying decision-making. In the case of landscape and seascape assessments, for example, visual 
impact analyses are undertaken by expert consultants, using a variety of visualising methodologies and producing artefacts such as maps, plans, photos and montages (Rydin et al., 2017). These depict the existing physical environment in specific ways (from certain angles, using certain technology, etc.) and then indicate how the yet-to-be-built project will fit within that environment. The scale and nature of the impact of the project is then described using technical language such as 'receptors' and 'sensitivity'. Finally, though, the impact is categorised in terms of severity and significance. This then enables the decisionmaking to proceed, moving the appreciation of landscapes and seascapes from a highly subjective, localised and emotional experience to the neutrality of expertise. The use of categorisation takes the complexity of different groups' appreciation of and attachment to a landscape and simplifies it to a set of labels denoting the scale of potential impact. This is an example of what Huxley call the "dispositional rationality of planning" (2006: 774), which uses grids of classification to draw boundaries and produce order on what would otherwise be positioned within regulation as chaotic and uncontrolled.

\section{Theme 3 - Black-boxing}

There is often a strong association between quantification and the construction of warrantable knowledge within regulation. This was evident with the evidence of ecological impacts of NSIPs (Lee et al., 2018; Rydin et al., 2018c). Where there are species that might be at risk, surveys are undertaken or drawn upon to establish the numbers of bats, newts, etc. involved. In the case of birds and aquatic species, such evidence is heavily mediated by quantitative modelling, to estimate the populations themselves and the impacts of the project on such populations. This knowledge generation is based in scientific institutions such as the governmental agency, Natural England and universities, but also consultancies 
and national NGOs. The complexity of the inter-relationships modelled and the requirement for assumptions in the face of limited data and empirical research means that considerable uncertainties necessarily remain over, say, the impacts of wind and tidal power on specific bird and fish populations (see Beauregard, 2018 on uncertainty).

This becomes a matter of concern for the regulators because, as indicated above, EU law requires a substantive conclusion on the integrity of protected habitats through assessing the impact on specific species. Thus, the models used to calculate ecological impacts become a focal point for discussion within the examinations. The question becomes: when does a model provide a 'serviceable truth'; when are the outcomes of modelling goodenough for regulation to proceed? Lee et al. (2018) refer to this as the co-production of law and knowledge, and of the authority associated with law and knowledge. This highlights the way that both the 'integrity' of a habitat and the 'impact' on that habitat are constructed 'facts' and how modelling is used to negotiate these. In the regulation of NSIPs, this involved generating agreement at the level of the likely impact rather than on the modelling processes themselves. Evidence from different modelling approaches and different model runs with new inputs or assumptions were presented to examinations and the key issue was whether the outputs of these modelling exercises were sufficiently close to each other to produce a calculation that could stand as evidence (Rydin et al., 2018c). This is a deeply pragmatic approach to knowledge.

Such pragmatism is also apparent when the contestation of knowledge claims occurs. Regulation of NSIPs is centrally involved with assessing knowledge claims and warranting them as sufficient evidence for decision-making. Yet knowledge claims remain inherently 
contestable and indeed are contested within regulatory debates. Here the concept of blackboxing is applicable, whereby details of how the knowledge claims were generated is contained by an emphasis on outputs (Rydin et al., 2018c). Participants may seek to open up the black box and contest key claims. However, the regulator - under time pressure to come to a reasoned decision - will resist too much contestation or proliferation of claims; they will move towards a conclusion or closure (Callon and Law, 2005). The regulatory process requires only the output of knowledge generation processes - the black box itself - to make rational decision-making possible. It does not need to know or adjudicate on how the knowledge is generated. When there are conflicting knowledge claims, they need only to be able to choose between them. This is sufficient to render the world judgeable and enable regulation to function. A number of strategies are deployed to achieve this. For example, there is the reliance on the explicit knowledge of an expert agency, such as Natural England, and the use of the artefact of the Statement of Common Ground to embed agreement and record an end to contestation. Such Statements are widely used within the NSIPs process to record agreement (and sometimes disagreement) on a variety of issues, but including methodologies, outputs of impact assessment methods and associated evidence. Where Natural England and the developer sign a Statement of Common Ground on, say, the methods and outputs of bird or fish modelling exercises, then this tends to close down further discussion.

A further example can be provided regarding knowledge claims about landscape and seascape impacts (Rydin et al., 2017). As discussed above, such impacts are subject to assessment processes involving key visualisation artefacts and categorisation. These are often contested by local actors who may offer critiques and alternative visualisations (as in 
Navitus Bay - see above). The way this contestation is closed down shines a spotlight on an under-considered aspect of regulation, the socio-materiality of the site visit. These involve the ExA, either accompanied by the applicant and Interested Parties or on their own, walking or sailing over the project site and visiting other areas that may be affected by connecting infrastructure and associated works. Here ExAs engage in an embodied encounter with the local area and use this to adjudicate on competing assessments of both the existing environment and the likely impact of the project. They frame their engagement with the local environment as the testing of artefacts (photos, etc) through experience with 'reality'; this is an example of the 'gaze' as a Foucauldian micro-practice (Fraser, 1992: 222).

In the light of the recent 'material turn' within planning studies (Beauregard, 2015; Beauregard and Lieto, 2016; Rydin and Tate, 2016), it is worth pointing out how certain material artefacts are implicated in these practices (Rydin et al., 2017). Modelling reports are a key example of such artefacts, important in constructing knowledge claims but also in moving knowledge around between different actors and organisations. The form of these knowledge artefacts also becomes significant when one considers how local publics can engage. Given the requirements for acceptable evidence within regulation to approximate expert formats and derive from scientific authority, local actors can struggle when putting forward their own knowledge claims. If they wish to provide evidence of impacts, they have to do so on equivalent terms to the developer, their consultants and the expert agencies (Tironi, 2015). However, they may not have the resources to do so and, even where they offer surveys and similar calculated knowledge, the rigour may be considered insufficient by the ExA for regulatory decision- making purposes. Here local NGOs can play a part as they may have more resources and greater capacity to engage in expert-framed debates about 
knowledge; the presence and involvement of such organisations did seem to widen the debates about the calculations relied on in regulatory decision-making and prevent premature simplification.

However, local actors may wish to offer knowledge in the form of narratives which do not approximate to these expert formats. In particular such actors experience of both their everyday lives and how they anticipate the future seems to be at odds with the approach to envisaging the future within the governmental institutions of regulation. Groves' work on anticipation is relelvant here (2017). He contrasts the forms of anticipation used within governmental contexts (in relation to energy infrastructure) with those of 'lived futures' associated with the communities where that infrastructure may be located. Governmental anticipation is characterised as linear and involving an emphasis on standardisation and legibility. The future is seen as abstract and emptied, needing to be 'filled up' at specific points of intervention (such as the punctuated trajectory of regulatory decision-making) by standardised, legible means (such as modelling exercises). Lived futures, by contrast, are characterised as fractal and spiral, so that "lived futures organise the space of public things differently" (2017: 35). In this way, challenging the black boxes of knowledge-as-evidence within NSIPs regulation (which are the dominant form of envisaging the future once the project is built) involves more than offering alternative knowledge claims in expert format; it could mean that regulation deliberations need to take on board a radically different sense of what lived futures in the vicinity of RE projects might be like.

\section{Conclusions}


The above analysis has shown how there are differential silences with the regulatory regime for major RE infrastructure which adversely can affect local residential and business communities, that there are constructed categories for considering local actors and project impacts that shape and limit decision-making, and that warranted knowledge, when considered as acceptable evidence for regulatory purposes is pragmatically constructed and black-boxed in specific accredited ways, making it difficult to challenge and taking a form that is at odds with the 'lived futures' of local people. While there are overt conflicts present - notably between the developer and local communities - these are only the visible surface of the iceberg of planning regulation. The framing of impacts means that some - notably ecological impacts - are given more space for consideration than others - notably local socio-economic impacts. In addition, there are implications of the way that the local actors and their voices are constructed within the regulatory process, which limits consideration of the concerns that local actors may have and the possibility for more complex stories about their lives and experiences to be present within the regulatory process. Then there is the way that national policy established through the NPSs favours such projects on the basis of national need, contributing to the experience of local communities that NSIPs are a 'done deal' and they are not being heard. It was further argued that knowledge dynamics exercised a diffused form of power. Regulatory processes are self-framed as rational and evidence-based, so that what counts as evidence matters. The analysis has drawn on ideas of knowledge as serviceable truths and the need to render the world judgeable through evidence in order for regulation to proceed; in addition, the contextual pressures of time have been emphasised. As a result the work of categorisation enables uncertain scientific knowledge to become useable and circulate readily between different actors. In addition, regulation of NSIPs involves considerable contestation of knowledge claims, but the 
regulatory process seeks to close down 'too much' contestation and this leads to blackboxing evidence and then seeking to keep those boxes closed. Expert agreement on outputs of black-boxing, fixed in an artefact or the embodied experience of the ExA are ways of achieving such closure.

While this analysis draws on the NSIPs regime operating in England and Wales and focusses on RE infrastructure, all planning regulation has certain common features: it has to handle the complexity and uncertainty of development and its likely future impacts and, then, move towards a decision within a time-limited context. There is a particular kind of work involved in resolving the tensions this generates, involving the distillation and simplification of the complexity of the development proposal to enable a decision to be taken. The tension between existential complexity and necessary judgement has to be negotiated and this results in the structuring of agendas and a pressure for the efficient handling of knowledge claims. It involves limiting the proliferation that can occur in knowledge claims (Callon and Law, 2005) and finding means of closure. It has been argued that finding ways to make regulation manageable is the deeply pragmatic task that all regulatory systems are engaged in. But this is not neutral work; it is laden with the exercise of power. This raises questions as to what could be proposed for addressing these relations of power and how this implicates normative planning theory.

One response - which could be said to sit broadly within a collaborative planning paradigm - is to find a procedural solution. This would look to redress the imbalances in access to regulatory arenas of different actors, thus fillings some of the identified silences, and allowing local actors, in particular, space to tell different stories of their complex, inter- 
leaved local lives. It gives rise to suggestions such as the proposal of a funding stream for local communities or greater use of informal arenas for local actors to be heard. The aim is to enable communities (broadly understood) to engage in regulatory debates on a more equal footing with the proponents of developments. Such an approach has been criticised by McClymont (2011) who sees such reforms as buying in to the failed promises of greater deliberation within planning and misleadingly suggesting that a more consensual outcome is possible. Instead she argues for celebrating conflicts within a framework of agonism, preferably within a local planning regime of regulation. But even this still accepts the frame of fixed identities and interests for local actors; it just frames them within the goal of enabling authenticity, as if different procedures will allow a more authentic account of local interests to emerge (Tate and Shannon, 2018).

The above analysis suggests that the relations of power spread through the capillaries of the regulatory regime in a way that resists a celebration of conflict in any simple way. Since the public sphere of communicative planning cannot be separated from power relations, one needs to be wary of accepting the normative claims of communicative planning (Huxley, 2000; Yiftachel and Huxley, 2000; Huxley and Yiftachel, 2000). Rather the way that practices fix identities of actors, embed assumptions about those actors and limit the definition and consideration of project impacts all need to be carefully addressed. There is a challenge here to consider how fluid, intersecting, comprehensive and indeed contradictory identities for actors can be given space within regulatory settings. This is less about determining local interests or even values and more about allowing different aspects of actors to emerge, permitting for fluidity in what counts as an actor, a person, an organisation. The current performativity of the regulatory process needs to be resisted. As Tironi argues, "a flexible 
ontology in which there are not only multiple identities, but also where any one identity can be potentially re-composed, re-invented or re-articulated" is required (2015: 86).

Similarly, the role that knowledge and evidence currently plays within the practices of regulation also needs to be reconsidered. The move to a more technocratic basis of regulatory decision making has been identified as post-political (McClymont, 2011: 253) and the black-boxing and modes of testing of knowledge within regulation may be considered to contribute to this depoliticization of regulation. In the case of NSIPs, it is clear that knowledge claims are overwhelmingly considered the domain of expertise; yet too great a focus on expertise can depoliticise planning decisions and contribute to power as domination. This raises fundamental questions about planning regulation that go beyond including more lay perspectives alongside expert knowledge; indeed, with Tironi (2015), it argues against enshrining knowledge and expertise only within certain actors' capacities.

So the question becomes: is it possible to find a way to base planning decisions on a wider range of criteria and move beyond an expertise-led and evidence-based system with all that this implies for how knowledge and evidence is constructed, claimed and warranted? This could include criteria that have greater meaning to local communities, both residential and business. It would also pose the challenge of whether the very categories of 'knowledge', 'expertise' and 'evidence' can be reconceptualised within planning regimes to broaden out their salience and incorporate a wider range of knowledge-makers. Foucault (1982: 211) suggests the productivity of starting with resistance to different forms of power and this suggests persisting with challenges to the way that planning regulation embeds certain identities for actors and certain forms of knowledge. To paraphrase Foucault here, the 
purpose would be to raise the fundamental question: what do we mean by knowledge in the field of ignorance and uncertainty?

This is a radical challenge to contemporary regulatory practice but may be one that needs to be tackled if the imbalances of power within regulation are to be adequately addressed. It may also mean tackling the normative assumption that planning as a set of practices is doing the 'right thing' and coming to the 'right decision'. Yiftachel states that "the days in which planners and planning were widely regarded as rational and progressive agents of change are well and truly over" (2001: 254; see also Lennon and Fox-Rogers, 2017) and yet normative planning theory continues the search for a normatively better form of planning practice. Drawing inter alia on Foucauldian ideas on power, Davoudi (2015) still finds a way to argue for a planning as a practice of knowing which is essentially positive. She sees this as encompassing knowing 'what', 'how' and 'to what end', which then leads to 'doing'; together this constitutes practice wisdom, a clearly positive term. While acknowledging that practices of knowing are situated and provisional, distributed and collective, pragmatic and purposive, and mediated and contested, she still sees potential for planners intrinsically to be playing a positive role. And yet not all knowing is positive. This is an ethical question that needs to be asked in each case. Planning based on eugenics knowledge claims would support an apartheid form of planning practice but, from a liberal perspective, should clearly be resisted.

Involved here is the deep challenge to normative planning theory posed by relational approaches such as those from Foucauldian and ANT traditions. With power and agency distributed, it is not possible to identify the oppressors and the oppressed, the 'good guys' 
and the 'bad guys'. Planners and planning organisations do have a role to play but it is not simply and structurally a normatively positive one. But what then follows? As Huxley asks: "Is it possible for planning practice and planning participation to foster transformative social change?" (2000: 376). There are two possible ways forward here suggested by the above analysis and worthy of further elaboration. First, the above discussion suggests the benefits of providing some degree of provisionality within regulatory regimes with retrospective redress for planning decisions that turn out to be harmful in the 'lived futures' of communities in the vicinity of development projects. Regulation would not, then, end with the 'right' planning decision or even monitoring of the conditions and agreements attached to that decision; it would be an acknowledged ongoing relationship between all the actors involved in and affected by the project that would require continuing spaces for engagement, challenge and resistance. Second, planning practice could no longer be seen as an inherently ethical enterprise but rather there would need to be spaces for exploring the ethical implications of such practice in different cases, considering what resulted from planning decision-making and how this reflects back on the idea of the planner as engaging in an ethical profession. This sees planning regulation as having a connected, continuing existence, rather than being a series of points of punctuated and time-limited decisionmaking. Both proposals suggest a much broader and ongoing visibility for regulation within the overall planning system and within planning theory.

\section{Acknowledgements}

Funding for the empirical research on the NSIPs regime, which is drawn upon here, was provided by ESRC under Award No: 164522; this was a collaborative research project with Maria Lee, Lucy Natarajan and Simon Lock (all at UCL), whose contribution to planning 
theory ideas emerging from the joint work is very much appreciated. The author also wishes to acknowledge the very helpful discussion at the 'City Matters' workshop held at SciencePo, Paris in September 2017 and organised by Robert Beauregard and Marco Cremaschi and specific comments on an earlier draft from Robert, Maria, Laura Lieto and Jonathan Metzger.

\section{References}

Beauregard, R. (2015) Planning Matter: acting with things Chicago, IL: University of Chicago Press

Beauregard, R. (2018) 'The entanglements of uncertainty' Journal of Planning Education and Research

Black, J. (2001) ‘Decentring regulation’ Current Legal Problems 54: 103-147

Callon, M, (1986) 'Elements of a sociology of translation: Domestication of the scallops and the fishermen of St Brieuc Bay' In J. Law (ed.) Power, Action and Belief: A New Sociology of Knowledge? London: Routledge, pp. 196-233

Cowell, R. and Devine-Wright, P. (2018) 'A 'delivery-democracy dilemma? Mapping and explaining policy change for public engagement with energy infrastructure' Journal of Environmental Policy and Planning

Davoudi, S. (2015) 'Planning as practice of knowing' Planning Theory 14(3): 316-331

Davy, B. (1997) Essential Injustice Wien: Springer

Davy, B. (2012) Land Policy: planning the spatial consequences of property Farnham, Surrey" Ashgate 
Devine-Wright, P. (2009) 'Rethinking NIMBYism: The role of place attachment and place identity in explaining place-protective action' Community and Applied Psychology 19(6): 426-441

Dreyfus, H.L. and Rabinow, P. (1982) Michel Foucault: beyond structuralism and hermenteutics Brighton, Sussex: The Harvester Press

Flyvbjerg, B. (1998) Rationality and Power: democracy in practice Chicago, IS: University of Chicago Press

Foucault, M. (1977) Discipline and Punish New York: Vintage Books

Foucault, M. (1982) 'Afterword: the subject and power' in H.L. Dreyfus and P. Rabinow Michel Foucault: beyond structuralism and hermenteutics Brighton, Sussex: The Harvester Press, pp. 208-226

Foucault, M. (1991) 'Questions of method' in G. Burchell, C. Gordon and P. Miller (eds) The Foucault Effect: studies in governmentality London: Harvester Wheatsheaf pp. 87-104 Fraser, N. (1992) 'Foucault on modern power: empirical insights and normative confusions' in P. Burke (ed.) Criticla Essays on Michel Foucault pp. 217-223

Gregson, N. and Rose, G. (2000) 'Taking Butler elsewhere: performativities, spatialities and subjectivities' EPD: Society and Space 18: 433-452

Groves, C. (2017) 'Emptying the future: on the environmental politics of anticipation' Futures 92: 29-38

Harris, N. (2011) 'Discipline, surveillance, control: a Foucauldian perspective on the enforcement of planning regulations' Planning Theory and Practice 12(1): 57-76 Huxley, M. (2000) 'The limits to communicative planning' Journal of Planning Education and Research 19: 369-377 
Huxley, M. (2006) 'Spatial rationalities: order, environment, evolution and government' Social and Cultural Geography 7(5): 771-787

Huxley, M. and Yiftachel, O. (2000) ‘New paradigm or old myopia? Unsettling the communicative turn in planning theory' Journal of Planning Education and Research 19: 333342

Jasanoff, S. (2015) 'Serviceable truths: science for action in law and policy' Texas Law Review 93: $1723-1749$

Kamete, A. (2011) 'Interrogating planning's power in an African city: time for reorientation?' Planning Theory 11(1): 66-88

Latour, B. (2005) Reassembling the Social: An Introduction to Actor-Network-Theory Oxford, Oxon: Oxford University Press

Lee, M. (2017) 'Knowledge of Landscape in Wind Energy Planning' Legal Studies 37(1): 3-24 Lee, M., Armeni, C., de Cendra, J., Chaytor, S., Lock, S., Maslin, M., Redgwell, C. and Rydin, Y. (2013) 'Public participation and climate change infrastructure' Journal of Environmental Law 25: $33-62$

Lee, M., Natarajan, L., Lock, S. and Rydin, Y. (2018) 'Techniques of knowledge in administration: co-production, models and planning law' Journal of Law and Society 45: 427456

Lee, M., Rydin, Y. and Lock, S. (2015) 'Public engagement in decision-making on major wind energy projects' Journal of Environmental Law 27: 139-150

Lennon, M. and Fox-Rogers, L. (2017) 'Morality, power and the planning subject' Planning Theory 16(4): 364-383

Lieto, L. and Beauregard, R. (eds) (2016) Planning for a Material World London: Routledge Lukes, S. (2005) Power: A radical view $2^{\text {nd }}$ Ed. London: Palgrave 
McClymont, K. (2011) 'Revitalising the political: development control and agonism in planning practice' Planning Theory 10(3): 239-256

Melossi, D. (2006) 'Michel Foucault and the obsolescent state: between the American century and the dawn of the European Union' in A. Beaulieu and D. Garrard (eds) Michel Foucault and Power Today Oxford, Oxon: Lexington Books, pp. 3-12

Merkus, S. and Veenswijk, M. (2017) 'Turning New Public Management theory into reality: performative struggle during a large scale planning process' Politics and Space 35(7): 12641284

Metzger, J., Soneryd, L. and Hallström, K. (2017) ' "Power" is that which remains to be explained: dispelling the ominous dark matter of critical planning studies' Planning Theory 16(2): 203-222

Miller, P. and Rose, N. (1990) 'Governing economic life' Economy and Society 19(1): 1-31 Morris, M. and Patton, P. (1979) Michel Foucault: power, truth, strategy Sydney: Feral Publications Murdoch, J. and Abram, S. (2002) Rationalities of Planning: development versus environment in planning for housing Aldershot, Hants: Ashgate Natarajan, L., Rydin, Y., Lee, M. and Lock, S. (2018) 'Navigating the participatory processes of renewable energy infrastructure regulation: a 'local participant perspective' on the NSIPs regime in England and Wales' Energy Policy 114: 201-210

Raco, M. and Imrie, R. (2000) 'Governmentality and rights and responsibilities in urban policy' Environment and Planning A 32(12): 2187-2204

Rouse, J. (2005) 'Power/Knowledge' Division I Faculty Publications, Paper 34 http://wesscholar.wesleyan.edu/div1facpubs/34 
Rydin, Y. and Tate, L. (2016) Actor Networks of Planning: exploring the influence of actor network theory London: Routledge

Rydin, Y., Natarajan, L., Lee, M. and Lock, S. (2017) 'Artefacts, the Gaze and Sensory Experience: mediating local environments in the planning regulation of major renewable energy infrastructure in England and Wales' in Rethinking Planning: tracing artefacts, agency and practice Kurath, M., Ruegg, J., Paulos, J. and Marskamp, M. (eds) London: Palgrave

Rydin, Y., Natarajan, L., Lee, M. and Lock, S. (2018a) ‘Do local economic interests matter when regulating Nationally Significant Infrastructure? The case of renewable energy infrastructure projects' Local Economy 33(3): 269-286

Rydin, Y., Natarajan, L., Lee, M. and Lock, S. (2018b) 'Local voices on renewable energy projects: the performative role of the regulatory process for major offshore infrastructure in England and Wales' Local Environment 23(5): 565-581

Rydin, Y., Natarajan, L., Lee, M. and Lock, S. (2018c) 'Black-boxing the evidence: planning, regulation and major renewable energy infrastructure projects in England and Wales' Planning Theory and Practice 19(2): 218-234

Tate, L. and Shannon, B. (2018) Planning for AuthentiCities New York, NY: Routledge Tironi, M. (2015) 'Modes of technification: expertise, urban controversies and the radicalness of radical planning' Planning Theory 14(1): 70-89 Van Oorschot, I. and Schinkel, W. (2015) 'The legal case file as border object: on selfreference and other-reference in criminal law' Journal of Law and Society 42(4): 499-527 Wagenaar, H. and Wilkinson, C. (2015) 'Enacting resilience: a performative account of governing for urban resilience' Urban Studies 52(7): 1265-1284 
Webber, S. (2013) 'Performative vulnerability: climate change adaptation policies and financing in Kiribati' Environment and Planning A 45: 2717-2711

Yiftachel, O. (2001) 'Can theory be liberated from professional constraints? On rationality and explanatory power in Flyvbjerg's Rationality and Power' International Planning Studies 6(3): $251-255$

Yiftachel, O. and Huxley, M. (2000) ‘Debating dominance and relevance: notes on the 'communicative turn' in planning theory' International Journal of Urban and Regional Research 24(4): 907-913 
Table 1

RE infrastructure cases studied

\begin{tabular}{|c|c|c|}
\hline Cases & Applicant & Scale \\
\hline $\begin{array}{l}\text { Kentish Flats Offshore } \\
\text { Wind Farm Extension }\end{array}$ & Vattenfall Wind Power Ltd & $\begin{array}{l}\text { 10-17 turbines; } \\
\text { 90-141 MW }\end{array}$ \\
\hline $\begin{array}{l}\text { Galloper Offshore Wind } \\
\text { Farm }\end{array}$ & $\begin{array}{l}\text { Galloper Wind Farm Ltd (RWE Innogy UK \& } \\
\text { SSE Renewables joint venture) }\end{array}$ & $\begin{array}{l}\text { Max } 140 \\
\text { turbines; } 504 \\
\text { MW }\end{array}$ \\
\hline $\begin{array}{l}\text { Burbo Bank Offshore } \\
\text { Wind Farm Extension }\end{array}$ & DONG Energy Burbo Extension (UK) Ltd & $\begin{array}{l}\text { Max } 69 \\
\text { turbines; } \\
259 \mathrm{MW}\end{array}$ \\
\hline $\begin{array}{l}\text { Rampion Offshore Wind } \\
\text { Farm }\end{array}$ & $\begin{array}{l}\text { E.ON Climate and Renewables UK Rampion } \\
\text { Offshore Wind Ltd }\end{array}$ & $\begin{array}{l}\text { Max } 175 \\
\text { turbines; } \\
700 \mathrm{MW}\end{array}$ \\
\hline $\begin{array}{l}\text { Walney Offshore Wind } \\
\text { Farm Extension }\end{array}$ & DONG Energy Burbo Extension (UK) Ltd & $\begin{array}{l}207 \text { turbines; } \\
750 \mathrm{MW}\end{array}$ \\
\hline $\begin{array}{l}\text { Triton Knoll Offshore } \\
\text { Wind Farm }\end{array}$ & Triton Knoll Offshore Wind Ltd & $\begin{array}{l}288 \text { turbines; } \\
1200 \mathrm{MW}\end{array}$ \\
\hline $\begin{array}{l}\text { Navitus Bay Offshore } \\
\text { Wind Farm }\end{array}$ & $\begin{array}{l}\text { Navitus Bay Development Ltd (Eneco Wind } \\
\text { UK \& EDF Energy joint venture) }\end{array}$ & $\begin{array}{l}\text { Max } 194 \\
\text { turbines; } \\
970 \mathrm{MW}\end{array}$ \\
\hline $\begin{array}{l}\text { Brechfa Forest West } \\
\text { Wind Farm }\end{array}$ & RWE NPower Renewables Ltd & $\begin{array}{l}\text { Max } 28 \\
\text { turbines; } 84 \\
\text { MW }\end{array}$ \\
\hline $\begin{array}{l}\text { Clocaenog Forest Wind } \\
\text { Farm }\end{array}$ & RWE Innogy UK Ltd & $\begin{array}{l}\text { Max } 32 \\
\text { turbines; } \\
96 \mathrm{MW}\end{array}$ \\
\hline $\begin{array}{l}\text { Swansea Bay Tidal } \\
\text { Lagoon }\end{array}$ & Tidal Lagoon (Swansea Bay) Power Ltd & $240 \mathrm{MW}$ \\
\hline $\begin{array}{l}\text { North Blyth Energy-from- } \\
\text { Biomass Plant }\end{array}$ & North Blyth Energy Ltd & 99.9MW \\
\hline $\begin{array}{l}\text { Rookery Energy-from- } \\
\text { Waste Plant }\end{array}$ & Covanta Rookery South Ltd & $65 \mathrm{MW}$ \\
\hline
\end{tabular}

